\title{
Electoral incentives, policy compromise, and coalition durability: Japan's LDP-Komeito Government in a mixed electoral system
}

\author{
Adam P. Liff ${ }^{1 \star}$ and Ko Maeda ${ }^{2}$ \\ ${ }^{1}$ Hamilton Lugar School of Global and International Studies, Indiana University, Bloomington, IN, USA and ${ }^{2}$ Department of \\ Political Science, University of North Texas, Denton, TX, USA \\ ${ }^{\star}$ Corresponding author. Email: aliff@indiana.edu
}

(First published online 5 December 2018)

\begin{abstract}
Political parties' behavior in coalition formation is commonly explained by their policy-, vote-, and officeseeking incentives. From these perspectives, the 20-year partnership of Japan's ruling conservative Liberal Democratic Party (LDP) and its pacifistic Komeito junior coalition partner is an anomalous case. The longevity, closeness, and nature of their unlikely partnership challenges core assumptions in existing theories of coalition politics. LDP-Komeito cooperation has sustained for two decades despite vastly different support bases and ideological differences on fundamental policy issues. LDP leaders also show no signs of abandoning the much smaller Komeito despite enjoying a single-party majority. We argue that the remarkable durability of this puzzling partnership results primarily from the two parties' electoral incentives and what has effectively become codependence under Japan's mixed electoral system. Our analysis also demonstrates that being in a coalition can induce significant policy compromises, even from a much larger senior partner. Beyond theoretical implications, these phenomena yield important real-world consequences for Japanese politics: especially, a far less dominant LDP than the party's Diet seat total suggests, and Komeito's remarkable ability to punch significantly above its weight and constrain its far larger senior partner, even on the latter's major national security policy priorities.
\end{abstract}

Keywords: Article 9; coalitions; constitution; electoral systems; Japan; Komeito; Liberal Democratic Party; LDP; policy; security

\section{Introduction}

Scholars generally consider policy-, vote-, and office-seeking to be three major drivers of political parties' behavior, and typically attribute the formation of coalitions between two (or more) parties to one or more of these objectives (Müller and Strom, 1999). This paper examines a major and long-lasting coalition generally overlooked by students of coalition politics; one whose remarkable durability challenges core assumptions of associated literatures and theoretical frameworks. It is also a coalition whose underlying mechanism exerts a practically significant real-world policy impact of importance to both scholars and policymakers.

The puzzling case at issue is the now 20-year-old partnership between Japan's conservative Liberal Democratic Party (LDP) - far and away the country's largest and most powerful postwar political party and its strange bedfellow and junior coalition partner, the relatively small, pacifistic Komeito, whose support base is a lay Buddhist organization, Soka Gakkai. Excluding the years 2009-2012, when the long-time opposition Democratic Party of Japan (DPJ) was in power, the LDP and Komeito have ruled Japan in a stable coalition since 1999. In addition to governing in coalition, they have also cooperated consistently and very closely in all seven general elections between 2000 and 2017, even when out of power. 
The existence and exceptional durability of this partnership presents several theoretical puzzles for students of coalition politics. For starters, one body of theoretical work expects coalitions to be formed by like-minded, policy seeking parties. Yet, the LDP and Komeito are strange bedfellows: ideologically incompatible in key policy domains central to their foundational party identities. Before an abrupt about-face in 1999, in fact, the two parties were sworn adversaries - on ideological and policy grounds. Politicians from the respective parties frequently displayed open contempt for the other's positions on major issues, and, in the case of many LDP politicians' disdain for Komeito, even opposed the other party's very existence as unconstitutional. Typically, parties aim to strengthen their brands to enact popular and effective legislation while blocking proposals that weaken that brand (Cox and McCubbins, 1993; Butler and Powell, 2014). One should therefore expect a coalition between parties with starkly different ideologies, identities, and/or policy preferences to be costly and, if anything, ephemeral. Predictably, the LDP-Komeito coalition is replete with internal frictions over policy, and both parties make costly concessions on core policy goals. And contrary to widespread discourse concerning the alleged 'dominance' of Japan's politics by the long-serving Prime Minister Shinzo Abe (2012-) and his LDP (e.g., Abe ikkyo), the much smaller Komeito has successfully stalled or significantly watered down some of Abe and his party's core policy initiatives, causing LDP Dietmembers to express frustration with and resentment toward the partnership. Yet despite these costs and the LDP's five consecutive national election victories since Abe's return as its leader in 2012, the coalition persists.

Relatedly, from a vote-seeking perspective, teaming up with an ideologically incompatible and clearly 'off-brand' party can be costly. When a staunchly conservative party (the LDP) partners with one with a largely pacifistic base (Komeito), or when core policy initiatives are hamstrung because of intra-coalition opposition, supporters may become disillusioned and reduce or cease involvement in party organizations, not turn out to vote, or even defect to another party. In short, by maintaining a coalition of such clearly strange bedfellows, both the LDP and Komeito risk alienating supporters.

Finally, from an office-seeking perspective, the LDP-Komeito coalition is also puzzling. Although the coalition formed when the LDP lacked a majority of seats in the Diet, the LDP has since regained a single-party majority in both houses. Because an office-seeking party should want to maximize the benefits of office, we should expect the LDP to have sought to terminate its partnership with Komeito and form a single-party cabinet. Yet it has not. And it shows no signs of interest in doing so.

Many partnerships of parties in the world's democracies are temporary and transient. Coalitions usually form based on straightforward considerations of which combination of parties would achieve a parliamentary majority $(50.1 \%$ of seats). Such transparently opportunistic coalitions are, unsurprisingly, superficial and often short-lived. Indeed, parties that join hands for short-term power maximization freely switch partners, and such behavior is the norm in many parliamentary democracies. For example, the Netherlands' Prime Minister Mark Rutte has formed three cabinets so far, each time changing coalition partners. The well-known exceptions are long-lasting coalitions in Australia (Liberal-National) and Germany (Christian Democratic Union and Christian Social Union). Yet, the policy positions of these partners are not radically different (Castles and Mair, 1984; Chanock and Ellis, 2003), to the extent that the German pair is even treated as a single party in datasets (e.g., the Manifest Project). In contrast, Japan's LDP and Komeito have vastly different policy positions on key issues; yet their partnership is also long-lasting.

While there is a rich literature on the durability of cabinets in parliamentary systems, scholarly attention has focused on how long cabinets last (e.g., Diermeier and Stevenson, 1999; Laver, 2003). The durability of parties' partnerships extending beyond an electoral cycle, even when both parties are in the opposition, receives far less attention. This is perhaps because scholars traditionally treat each coalition formation as a fresh new game. In contrast, this paper's analysis of Japan's LDP and Komeito focuses on explaining the puzzling durability of their partnership over multiple election cycles, thereby contributing to theoretical research on coalitions from this understudied perspective.

Another theoretical issue this study touches on relates to policy decision-making in coalition cabinets. As shown in Figure 1, the LDP's Diet seats vastly outnumber those of its junior coalition partner. From a conventional perspective, one would expect that when two parties of vastly different sizes form 


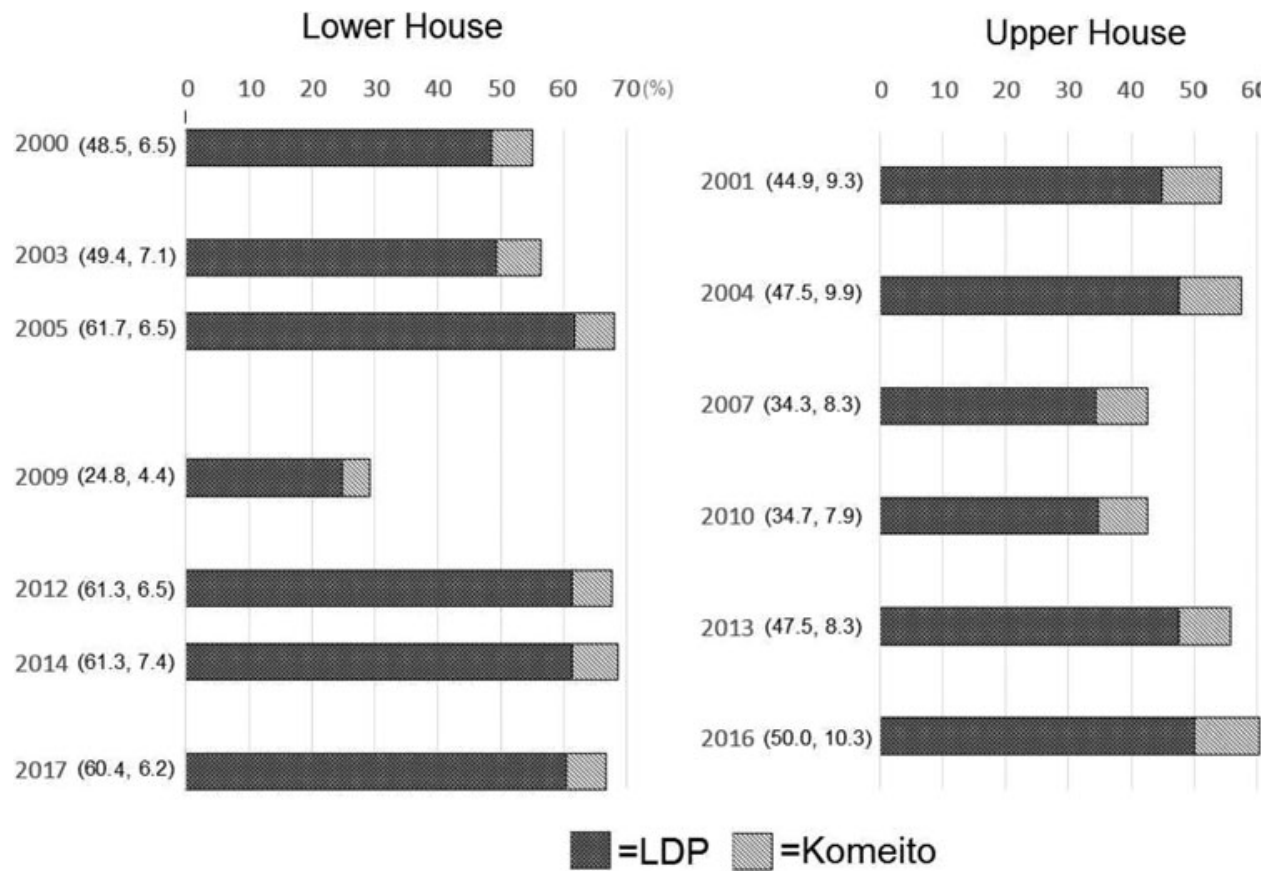

Figure 1. Relative Diet strength since the first LDP-Komeito ruling coalition (1999). Note: The bars in the graph show the seat shares (\%) of the LDP and Komeito after each national election. Aggregate electoral results are available at the government's website at http://www.soumu.go.jp/senkyo/senkyo_s/data/index.html

a coalition the larger party's policy preferences would prevail over the smaller party's, especially on issues the larger party and prime minister have repeatedly identified as top priorities. ${ }^{1}$ Consistent with this theoretical expectation, a recent study on the LDP-Komeito coalition's impact on policy argues that Komeito's small size and limited strength leave it unable to influence the LDP 'in a noteworthy way, even if Komeito display[s] strong persistency and determination' (Hasunuma and Klein, 2014: 260). ${ }^{2}$ In contrast, our analysis reveals that Komeito has in fact exerted significant policy influence disproportionate to its small size. In key instances, it has even forced the LDP to make major policy concessions on core domestic and foreign policy priorities fundamental to LDP's identity and platform since the party's founding in 1955. Most theoretically compelling among these relate to policy matters seen by many within the LDP as increasingly urgent national security imperatives as Japan struggles to respond to perceived threats from an increasingly powerful and assertive China and North Korea's increasingly robust nuclear and ballistic missile arsenal, as well as concerns about the declining relative power of its U.S. ally and perceived ambivalence in Washington about the U.S. commitment to Japan's security. Abe has even explicitly identified these policy priorities as his 'generation's mission' and the focus of his personal (and family's) political legacy. Theoretically, these remarkable LDP concessions raise important questions about the sources of Komeito's leverage over its much larger coalition partner. Empirically, they challenge the widespread narrative of Abe and the LDP's alleged 'dominance' of Japan's politics today.

Despite the aforementioned reasons why, from a theoretical perspective, the LDP-Komeito coalition is very unlikely, after nearly two decades it persists. This puzzling partnership of unlikely

\footnotetext{
${ }^{1}$ Of course, this rule does not necessarily apply if the larger party lacks a majority and needs the smaller party's seats. Yet, the LDP has a single-party majority.

${ }^{2}$ There has also been a journalistic argument that the LDP's single-party majority gives Abe more freedom in his actions. Nihon Keizai Shimbun, “Shusho wa komeito wo kirunoka’ hamon yobu 15fun no kaidan,” 24 March 2017.
} 
bedfellows challenges core assumptions of associated literatures and theoretical frameworks. Why is it so durable?

In this paper, we systematically demonstrate the extent of LDP-Komeito codependence and show how it derives primarily from Japan's mixed-member majoritarian electoral system. In essence, a major reform of Japan's electoral system in 1994 introduced single-member districts (SMDs), in which the relatively small Komeito had immense difficulty competing independently. Since forming a coalition in 1999, however, the LDP and Komeito have developed a systematic scheme of electoral cooperation in which they agree to mutually 'stand down' so as not to compete in SMDs, and also coordinate candidate nominations (see Section 4). This cooperation enables otherwise unlikely Komeito victories in SMDs where the LDP 'stands down'. In exchange, Komeito agrees to abstain from fielding a candidate and to mobilize its exceptionally loyal support base - politically active adherents of Soka Gakkai - to deliver votes to LDP candidates in other SMDs. The basic fact that the two parties help each other in elections may be known to most scholars of Japanese politics, but this study goes much further to clearly demonstrate why the precise nature and structure of their codependence makes it very difficult (electorally costly) for either party to end the partnership. This, in turn, explains why the coalition has proven so exceptionally durable over the past 20 years and why the two parties are willing to make significant policy compromises to sustain their partnership. We also show that the mechanism underpinning the codependence is unobservable based on the traditional logics of coalition politics. Additionally, we employ district-level electoral data and robustness checks to evaluate the extent of codependence rigorously.

This paper's findings have general implications for associated theoretical literatures in comparative politics, particularly as it concerns coalition building and durability, even in instances of significant disconnects between partners concerning ideology or policy preferences. The type of electoral cooperation which manifests in the case of Japan's LDP-Komeito partnership is unlikely to emerge in proportional representation (PR) electoral systems, which are common in Europe. This new mode of electoral cooperation and source of pre- and post-election coalition durability also contributes to the field's understanding of party politics.

This study also contributes to our understanding of Japanese politics and foreign policy. It helps illustrate the conditionality and underappreciated weakness of the LDP's electoral base and its hold on a Diet majority. It also highlights the widely overlooked but practically significant, if inconspicuous, influence the much smaller Komeito exerts over the LDP-dominated Cabinet's policy decisionmaking. Two case studies demonstrate Komeito's crucial role in frustrating two of the Abe administration's three signature policy initiatives since 2012: efforts to enable 'full' collective self-defense (CSD) operations and to revise Japan's constitution. ${ }^{3}$ They reveal how this electoral-incentive driven partnership yields significant and costly policy compromises that, in turn, allow these two strange bedfellows to continue working together.

\section{Coalitions in parliamentary democracies}

Who controls the executive branch is a fundamental question in any political system. In parliamentary democracies, the numbers of seats each party holds usually determines the answer. As such, when no single party attains a majority, inter-party negotiations are usually necessary to form a coalition government. As Laver and Schofield note, 'understanding how a given election result leads to a given government is, when all said and done, simply one of the most important substantive projects in political science' (Laver and Schofield, 1990: 89).

In the literature on cabinet formation, the most prominent approach focuses on parties' relative sizes, typically measured by seat totals. Because a cabinet is terminated when a majority of legislators pass a vote of no confidence, controlling a majority of legislative seats is a primary concern of political parties as they battle for political power and influence over policy. Minority cabinets sometimes form,

${ }^{3}$ The third is economic policy; popularly referred to as 'Abenomics.' 
but are not common. ${ }^{4}$ When parties negotiate to form a coalition, they must always be mindful of which combination of parties (and associated constellations of policy preferences) would control a majority, and which combination would not.

In addition to the overriding objective of securing a majority of parliamentary seats, parties and their leaders also wish to avoid a coalition that is larger than necessary. Riker's seminal study argues that minimal winning coalitions are to be expected as members seek to maximize their potential payoff - as he puts it, 'In social situations similar to n-person, zero-sum games, with side-payments, participants create coalitions just as large as they believe will ensure winning and no larger' (Riker, 1962: 47). A minimal winning coalition is a combination of parties that collectively controls a majority of seats but which does not include any party beyond what is necessary to achieve a majority. The logic behind Riker's prediction is that, if parties seek to maximize power or office benefits, they should not allow any parties into a ruling coalition beyond a level minimally necessary to give the cabinet majority status. Relatedly, Leiserson (1968) predicts that parties will end up with a combination that controls a majority with the fewest number of parties possible because having few parties makes bargaining easier. In summary, theoretical considerations about party sizes and coalition formation expect minimal winning coalitions. Empirical studies have generally found supportive evidence for this claim (e.g., Martin and Stevenson, 2001). The oversized coalition of the LDP and Komeito is thus an anomaly.

Importantly, the aforementioned studies focus on the sizes of parties. They do not consider the agendas or policy positions of potential coalition partners as a factor in coalition formation. But since parties appeal to voters with their principles, platforms, and promises, they also care greatly about the policy preferences of others when negotiating the formation of a coalition. Axelrod (1970) argues that a majority controlling coalition should form among parties whose policy preferences are adjacent on the ideological spectrum, which would minimize the transaction costs of bargaining. Similarly, de Swaan (1973) expects the formation of a minimal winning coalition that minimizes the ideological range of the participating parties erstwhile. Empirical studies have generally confirmed that coalition formation is more likely among parties with similar ideological positions (e.g., Martin and Stevenson, 2001). Once again, the LDP-Komeito coalition does not fit with the empirical pattern, challenging conventional wisdoms.

In addition to sizes and policy positions of parties, the theoretical literature on coalition formation has also analyzed institutional characteristics that constrain parties' coalition behavior. A study by Strom, Budge, and Laver (1994) is one of the earliest to engage this line of inquiry. In contrast to earlier studies, which treated political parties 'as if they were unconstrained players in an institution-free world' (Strom, Budge, and Laver, 1994: 303), it argued that various institutional factors reduce the range of coalition options (also see Lupia and Strom, 1995 and Muller and Strom 2000). Electoral systems are an important institutional factor that influences parties' strategies. Strom, Budge, and Laver (1994) argued that 'the Irish STV system, the French double-ballot system, and the British simple plurality system' provide incentives for parties to form a pre-electoral coalition, and 'Coalition bargaining is thus moved forward to the period before the election' (pp. 315-316). The disproportional nature of those electoral systems creates an environment in which it is beneficial to form an alliance to reap economies of scale. Parties' electoral strategies and coalition behavior are thus connected. Golder's (2006) work on pre-electoral coalitions analyzes the mechanism under which parties form an electoral alliance while committing to a formation of a legislative coalition. She identifies three variables that increase the likelihood of a pre-electoral coalition. First, the parties tend to be ideologically compatible. Yet, as we will discuss below, on key priorities the LDP and Komeito are not. Second, their combined size should be large but not too large. This is consistent with the classic expectation that minimal winning cabinets are the predicted outcome. Yet today the LDP and Komeito continue to cooperate in national elections and rule in coalition despite the LDP having regained a single-party majority. Third, they should be similar in size. Yet, again, the LDP-Komeito case is contrary to theoretical

${ }^{4}$ In a recent study of 31 parliamentary systems, minority cabinets emerged only $18 \%$ of the time (Lijphart, 2012: 87). 
expectation, as the LDP comprises the vast majority of coalition seats in the Lower House. The LDPKomeito partnership therefore is also anomalous from the perspective of pre-electoral coalitions in parliamentary systems. ${ }^{5}$

In sum, although existing theories tell us a lot about coalition formation generally, they struggle to explain the durability of a puzzling pre- and post-electoral coalition like the post-1999 partnership between Japan's LDP and Komeito. What is keeping this odd couple together?

\section{The real dynamics of Japan's ruling LDP-Komeito coalition}

Beyond the general theoretical puzzle Japan's ruling coalition presents to students of coalition politics, characteristics specific to these two parties make it all the more surprising that they have cooperated so closely for two decades.

\subsection{Background on the parties}

Since the merger of two conservative parties created the LDP in 1955, it has been postwar Japan's perpetually ruling party, with the exception of two brief inter-regnums in 1993-1994 and 2009-2012. Since its founding, the LDP has adopted a pro-US orientation and supported economic policies that favor business and agricultural sectors. The party has also sought to 'rid Japan of the post-war regime' (sengo rejımu kara no dakkyaku) that its members see as shackling Japan on issues running the gamut from education to the development of a more robust, independent, and 'normal' national security posture. Especially in, but not limited to, the period since the Soviet Union's collapse, the LDP has championed increased defense spending and a more assertive defense posture consistent with international major-power norms. Central to this push have been the LDP's repeated attempts to revise the Article 9 'peace clause' of Japan's U.S.-drafted and never-amended 1947 Constitution, and to significantly expand the Japanese Self-defense Forces' (JSDF) mandate to, inter alia, enable the full exercise of military force under the U.N. Charter-sanctioned right of 'collective self-defense' to aid an ally under attack. Over the past two decades, each of these issues has become a front-burner concern for the LDP, one on which the Prime Minister Abe has repeatedly stated he intends to stake his political life.

Komeito's origins and views on such issues stand in stark contrast to that of the conservative and much larger LDP. Komeito was founded by the lay Buddhist movement Soka Gakkai in 1964, with the stated goal of bringing 'Buddhist democracy' to Japan. The party's defining principles are pacifism, social welfare, and humanistic socialism. For most of the decades of single-party dominance by the conservative LDP, Komeito was the third largest party after the left-wing Japan Socialist Party (JSP). Though Komeito often advertised itself as a 'middle way' (chudo) party, in its early years it was seen by many in the LDP and beyond as an affront to the constitutional separation of religion and politics. In response to such criticisms, in 1970 Soka Gakkai and Komeito officially cut organizational ties. To date, however, almost all Komeito politicians have been adherents of Soka Gakkai. As noted earlier, Soka Gakkai's followers provide a singularly powerful and reliable organized bloc of religious voters that is the envy of other political parties, especially as the political influence of other interest groups in Japan has declined significantly in recent years. ${ }^{6}$ In a comparative context, Komeito can be thought of as a 'small mass party' (Smith, 2014). Significant for the case studies below, many

\footnotetext{
${ }^{5}$ Golder's (2006) seminal book on pre-electoral coalitions examines data from 23 countries, including Japan, for a period of 1946-2002. The partnership of the LDP and Komeito in the 2000 election is not counted as a pre-electoral coalition in her data, however. Presumably, this is because the two parties' coordinated candidate nomination was not perfect in 2000. Circumstances have changed significantly in the interim (see Section 4).

${ }^{6}$ Ehrhardt et al. (2014a) provide excellent background on related issues. On history, see Ehrhardt et al. (2014b). On voter participation and mobilization, see Klein and Reed (2014a, 2014b); McLaughlin (2014); Ehrhardt (2014a; 2014b). On candidate nominations, see Smith (2014). Komeito's English name has changed several times; for clarity we use its current name throughout this paper.
} 
pacifistic members of Komeito and Soka Gakkai are known to staunchly oppose core policy preferences of the much larger and deeply conservative LDP on national security, constitutional revision, and related matters. Though in the era of cooperation the two parties' official platforms contain some overlap, on two of the defining issues for Japan (and the LDP) throughout the postwar era national security and the constitution - the two parties' substantive policy differences are longstanding and significant.

\subsection{The post-1999 coalition}

For these reasons, the 1999 birth of the LDP-Komeito coalition was hardly preordained. For decades prior, there was no love lost between the two parties, a reality reflected in developments in the years immediately before the coalition's formation. Indeed, the first time Komeito joined a coalition government (1993), it was one formed in direct opposition to the LDP. Meanwhile, in subsequent years the LDP clawed its way back into power in part by mobilizing other religious groups against Komeito. It argued that (Buddhist movement-backed) Komeito's very existence as a political party was a threat to democracy and violation of Article 20 of Japan's Constitution, which prohibits religious organizations from exercising 'any political authority.' For example, in 1993 an LDP member formed an association to oppose Komeito's participation in government as a grave threat to the country's future. Ironically, given the coalition's formation a mere 6 years later, the anti-Komeito movement within and outside the LDP argued that it 'cannot allow a religious group to be closely connected to political power' (Klein and Reed, 2014b: 215-216, 221-229). By 1995, an LDP special research committee on 'religious organizations and social order' lumped Soka Gakkai together with the religious/terrorist cult Aum Shinrikyo, which that year launched a massive terrorist attack on the Tokyo subway that killed thirteen and injured thousands. The LDP's secretary general attributed the LDP's 1995 election success to running against the mixing of religion and politics. Its anti-Komeito campaign continued (Klein and Reed, 2014b).

Yet political desperation following a historic defeat in 1993, which knocked the LDP out of power for the first time since 1955, eventually led to a change of heart. By the mid-1990s it was back on its feet and soon restored single-party government. Two years later, in July 1998, the LDP looked to regain control of the House of Councillors. Contrary to expectation, however, it suffered a devastating electoral blow that left it in the minority - creating a divided Diet. To end this state of affairs, in a fateful step in October 1999 the LDP invited Komeito, its erstwhile ideological and political nemesis, to rule in coalition. ${ }^{7}$ Though Komeito's policy preferences aligned far more closely with the leading opposition, left-of-center DPJ, it had the number of seats the LDP needed. Nevertheless, even after its formation many LDP party members continued to oppose the coalition on ideological grounds. Some even signed a declaration formally opposing the alliance. The reasons varied, but one of the most significant was contempt for Komeito's support base: Soka Gakkai (Klein and Reed, 2014b).

Yet the rest is history, if ironic. Since 1999, the two parties have maintained a deep partnership in government, with the sole exception of when the 2009-2012 period of DPJ rule put both parties in the opposition, and in national election campaigns. The LDP has always been far larger than Komeito, a trend that continues in the Abe era (see Figure 1). Though it has attracted remarkably little attention from students of coalition politics, this puzzling partnership between long-time adversaries who hold starkly different positions on key policy issues has fundamentally shaped contemporary Japanese politics, and major policy outcomes, for two decades. Why and how such qualitatively distinct parties have managed to form, strengthen, and maintain for so long a durable and robust partnership in governance and national election campaigns carries important implications for associated theoretical literatures. Of additional theoretical and practical import: how Komeito has been able to extract significant policy concessions from the much larger LDP on issues central to its conservative senior

\footnotetext{
${ }^{7}$ Initially, this coalition also included the Liberal Party. That party soon split, and the group which remained in the coalition was later absorbed into the LDP in 2003.
} 
partner's very creation in 1955 (see Section 6 case studies). The answers are also foundational to understanding contemporary Japanese politics, and for evaluating both the policy legacy of the post-2012 Abe era and the likelihood of major structural change in the years ahead.

\section{Explaining the puzzle: mutual dependency induced by the electoral system}

We argue that the puzzling durability of the stable, 20-year LDP-Komeito partnership is effectively an equilibrium owing to Japan's electoral system and the two parties' highly complementary organizational characteristics and electoral strengths. Major electoral reforms in the early 1990s created the structural conditions necessary for the emergence of deep codependency between these erstwhile adversaries. A quarter-century later, both parties now rely on the other for continued electoral success. This codependency has deepened over seven general elections, and is far more practically consequential than what existing theory - or simply a straightforward tabulation of respective seat totals - would presume about the coalition's underlying conditions, each party's respective Diet strength, or their respective intra-coalition influence. As we explain below, this situation is not expected in pure PR systems. Because most scholarly work on coalition politics has focused on countries with pure PR systems, where coalitions are more often observed, the mechanism underpinning the remarkably durable LDP-Komeito ruling coalition is atypical in the study of coalition politics.

Specifically, the enabling conditions of the LDP-Komeito's partnership can be traced to 1994, when a (non-LDP) ruling coalition pushed through the Diet a major reform of the Lower House electoral system which created an SMD tier (currently 289 seats) and a PR tier (currently 176 seats spread across 11 PR districts). Unlike Germany's or New Zealand's systems, where PR seats are allocated to parties so that parties' total seats (the sum of PR seats and SMD seats) become proportional to their PR vote shares, Japan's mixed system consists of two tiers insulated from each other. Accordingly, voters elect members of the Diet independently in the SMD tier and the PR tier. Eight general elections have been held under the new system since it was first used in 1996 (1996, 2000, 2003, 2005, 2009, 2012, 2014, and 2017). The LDP-Komeito coalition formed in 1999 - after the first election held under the new system, but before the second. The parties have cooperated closely in all seven Lower House elections since.

As discussed earlier, simple arithmetic aimed at gaining control of a majority of parliamentary seats is usually the primary driver of most coalition formations. Indeed, the original purpose of the LDPKomeito coalition was similarly straightforward: the LDP wished to attain a majority in the Upper House to end a divided Diet. Once the parties started working together, however, they were soon forced to confront an important challenge: how to nominate candidates in the SMD tier. After all, since each SMD contains only one Diet seat, the nascent partners would hurt each other in every district where both parties nominated candidates. To avoid this outcome, the LDP and Komeito began to coordinate candidate nominations in SMDs. Initially, there were hiccups: in the 2000 election - the first general election after the coalition's formation - there were four SMDs in which both parties fielded candidates. ${ }^{8}$ This election marked the first and last time the nascent partners directly competed in SMDs, however. In the 2017 election, for example, the LDP nominated 277 candidates across 277 SMD districts and Komeito nominated nine candidates across nine SMD districts. Overlap has been eliminated since the 2003 election.

The fact that the two parties have complementary comparative advantages geographically facilitated such cooperation. Specifically, the LDP has an electoral advantage in rural areas, while Komeito is primarily an urban party. This complementarity made it easier for each party to stand down in districts where the other wanted to run a strong candidate. In contrast, the DPJ - the main rival to the LDP at that time - was, like Komeito, stronger in urban areas. Though the DPJ and Komeito were more ideologically compatible, such geographical overlap would have been an important obstacle to a hypothetical DPJ-Komeito coalition. One implication: the LDP and Komeito are uniquely well-suited to cooperate electorally and have no clear alternative partners.

\footnotetext{
${ }^{8}$ The LDP won in two of them, and Komeito did not win any. See Figure 1 data source.
} 
If the first step of the LDP and Komeito's electoral coordination was to stop nominating competing candidates in SMDs, the natural next step to maximize the coalition's success nationally was for the two parties to help each other in SMDs where either coalition member was running a candidate. Because mutual 'stand down' agreement in SMDs meant that districts where the LDP runs a candidate have no Komeito candidates running (and vice versa), it is logical to expect that Komeito would have an interest in mobilizing its supporters in LDP-designated SMD districts to vote for LDP candidates. Conversely, Komeito's SMD candidates would benefit from LDP supporters' votes. Indeed, one would expect most Komeito candidates would probably not win without LDP cooperation.

Coalition practice conforms to this logic. The two parties' deepening electoral cooperation manifests in increasingly frequent cross-recommendations of SMD candidates. In 2000, Komeito formally recommended 156 of the LDP's 271 SMD candidates (58\%). ${ }^{9}$ Kawato (2002) shows that the LDP candidates with Komeito recommendations obtained additional votes in that election. That percentage increased to $71 \%$ in the next election (2003), and then to $82 \%$ (2005), 94\% (2009), 80\% (2012), $92 \%$ (2014), and 96\% (2017) in subsequent elections. These statistics evince Komeito's deepening support of the LDP and suggest that more and more LDP candidates are also courting Komeito for its support. Indeed, whereas in 2000 the LDP recommended 78\% (14 of 18) of Komeito's SMD candidates - i.e., all those Komeito candidates that did not face an LDP challenger ${ }^{10}$ - since 2003, when the partners began coordinating perfectly (i.e., no coalition candidates compete in any SMD), the LDP has recommended all Komeito SMD candidates.

As LDP-Komeito cooperation in SMDs has deepened, candidates from each party have come to increasingly rely on support from the other. LDP candidates under the old electoral system were able to win reelection by maintaining stable support organizations for their individual campaigns (Krauss and Pekkanen, 2010). But the 1994 electoral reform was transformative. Ever since, Japan's elections have become increasingly party centered, and individual candidates' electoral fortunes correlate with their parties' (or party leaders') popularity (Maeda, 2009). Meanwhile, voters' party identity has also become far more fluid, or absent: Whereas less than $10 \%$ of voters were without a party affiliation in the 1960s, by the eve of the 2012 landslide election that returned Abe and the LDP-Komeito coalition to power, unaffiliated (mutoha) voters made up the majority of the electorate (Tanaka, 2012).

In this far more unpredictable post-reform electoral context, the LDP's support base is far shakier than its recent electoral success measured in Diet seat totals would suggest - a fact rendered abundantly clear by the LDP's (and ruling coalition's) landslide defeat in 2009, which ushered in three years of rule by the theretofore opposition - and now defunct - DPJ. Given this significant uncertainty, LDP candidates have come to deeply value the stable support base provided by Komeito, whose voters are famous for their loyalty and reliability. ${ }^{11}$ The major takeaway is this: If the LDP were to end its partnership with Komeito, most LDP candidates would probably lose a significant chunk of votes. Especially for LDP SMD candidates accustomed to tens of thousands of votes from Komeito supporters, the result could be disastrous. No counterfactual is possible in a national case, since the two parties have cooperated in every election since 1999. However, local elections provide some imperfect support. Most recently, it was widely reported that one major factor in the LDP's shocking loss in the 2017 Tokyo metropolitan government assembly election was Komeito's decision not to cooperate with it. Whereas only roughly one-in-three LDP candidates won, all Komeito candidates were victorious (see Conclusion).

Komeito support for LDP candidates is hardly charity, of course, and the two parties' electoral coordination benefits Komeito candidates as well. For starters, it is well known that SMD elections

\footnotetext{
'The data for parties' recommendations of other parties' candidates were taken from newspaper reports as they appeared in Yomiuri Shimbun (29 August 2009) and Asahi Shimbun (14 June 2000; 4 November 2003; 10 September 2005; 14 December 2012; and 11 December 2014). For the 2017 election, data come from Asahi Shimbun's website at http://www.asahi.com/.

${ }^{10}$ In five of the fourteen districts, LDP members who were denied their party's endorsement ran as independents against the LDP-recommended Komeito candidate (Curtis, 1999: xvi).

${ }^{11}$ Komeito arguably provides a more reliable support base for LDP politicians than LDP supporters themselves (Klein and Reed, 2014b: 232).
} 
disproportionally favor large parties and disadvantage small parties (Duverger, 1954; Lijphart, 1994). For a relatively small party like Komeito, whose PR vote shares are typically $12-14 \%$, winning SMD seats on its own would be very difficult. Running as a 'unified candidate' from the LDP-Komeito coalition, in contrast, significantly improves a Komeito SMD candidate's electoral prospects. As noted above, because of mutual stand-down agreements, since 2003 no Komeito SMD candidate has had to face an LDP competitor. Each election, the LDP sets aside several (usually, 8-10) districts for Komeito candidates and offers them the party's recommendation. In the vast majority of cases (the historic 2009 DPJ's landslide victory a major exception), these LDP-backed Komeito SMD candidates have won. ${ }^{12}$

It is true that Japan's electoral system has a PR tier in addition to SMD, and even small parties can win seats in PR districts. Once upon a time, Komeito leaders considered the option of abandoning SMDs and instead focusing exclusively on PR. ${ }^{13}$ For example, after the LDP-Komeito coalition's 2009 landslide defeat, in which all eight Komeito SMD candidates lost, Komeito President Natsuo Yamaguchi publicly stated that the party would consider withdrawing from SMD races completely. After a backlash from within Komeito, however, he retracted his statement. Since roughly one-quarter of Komeito's Lower House seats come from the SMD tier, abandoning it would risk enervating the party's role in national politics. And ending its partnership with the LDP would put most, perhaps all, those SMD seats at risk. In short, Komeito needs the LDP, too.

Of course, Komeito's close cooperation with the LDP is not without costs. For good reason, the Komeito leadership is perennially concerned about alienating existing supporters; especially those in its pacifistic base who strongly oppose the LDP's agenda on certain issues (e.g., constitutional revision; national security). ${ }^{14}$ Yet, the well-known loyalty and stability of Komeito supporters - many of whom are adherents of the same Soka Gakkai movement - gives the party leadership some slack. In addition, to please supporters Komeito politicians routinely (and credibly) emphasize the role Komeito plays within the coalition as moderating force (a 'brake') on the LDP's more ambitious policy agenda. Even if some of the party's supporters are skeptical, for politicians accustomed to the office and electoral benefits the partnership has provided Komeito the past two decades, ending the partnership would almost certainly prove extremely costly.

The coalition is also costly for the LDP. In the following sections, we first measure the degree of LDP candidates' dependence on Komeito supporters' votes in SMDs. We then use two case studies to demonstrate the significant leverage this inconspicuous electoral reality grants the LDP's much smaller junior coalition partner in intra-coalition negotiations over several core LDP policy priorities.

\section{Unmasking the façade of dominance: LDP candidates' electoral reliance on Komeito supporters in SMDs ${ }^{15}$}

To what extent do LDP candidates in SMDs rely on votes from Komeito supporters to get elected? In the seven lower house elections from 2000 to 2017, the LDP nominated 1,976 SMD candidates, of which 1,302 (66\%) won. ${ }^{16}$ How many would have lost without Komeito support? The counterfactual is of course impossible to know for certain, but below we develop a simulation to shed light on the likely answer.

\footnotetext{
${ }^{12}$ Except for the 2009 election, when the LDP-Komeito coalition suffered a major loss, the winning percentage of Komeito's SMD candidates from 2003 to 2017 is $93 \%$ (43 out of 46). In 2009, all nine SMD candidates of Komeito were defeated. The data sources are noted in Figure 1.

${ }^{13}$ Yomiuri Shimbun, 25 July 2010.

${ }^{14}$ Mainichi Shimbun, 24 September 2018. Also, Onizuka (2002) discusses the possibility that a party that joins an LDP-led coalition alienates existing support.

${ }^{15}$ District-level results of SMDs were taken from newspaper websites after each election. For the 2017 election, the data were provided by Yuki Yanai (Kochi University of Technology). In addition, we use PR vote data broken down by SMDs. The data were constructed by first obtaining municipality level PR vote results from prefectural electoral commissions' websites and then aggregating the vote totals by SMDs. For a few SMDs that cut across municipalities, the exact numbers were unobtainable and are estimates. The data for the 2017 election were provided by Kuniaki Nemoto (Musashi University).

${ }^{16}$ The 1996 election is excluded because the LDP-Komeito coalition started in 1999. Japan's electoral law allows SMD candidates to also run in the PR tier, and candidates who lost in an SMD may still secure a PR seat. Yet, in this analysis
} 
Table 1. Expected consequences of an end to LDP-Komeito electoral cooperation in SMDs (80\% assumption)

\begin{tabular}{|c|c|c|c|c|c|c|c|}
\hline Year & 2000 & 2003 & 2005 & 2009 & 2012 & 2014 & 2017 \\
\hline No. of LDP candidates in SMDs (actual) & 271 & 277 & 290 & 289 & 289 & 283 & 277 \\
\hline No. of LDP winners in SMDs (actual) & 177 & 168 & 219 & 64 & 237 & 222 & 215 \\
\hline $\begin{array}{l}\text { Would-be LDP winners in SMDs after subtracting } 80 \% \text { of Komeito supporters' } \\
\text { votes (simulated) }\end{array}$ & 129 & 91 & 151 & 30 & 199 & 163 & 153 \\
\hline Net loss of lower house Diet seats for LDP (SMD only; simulated) & -48 & -77 & -68 & -34 & -38 & -59 & -62 \\
\hline $\begin{array}{l}\text { Implied percentage of victorious LDP SMD candidates who won due to } \\
\text { Komeito support }\end{array}$ & $27 \%$ & $46 \%$ & $31 \%$ & $53 \%$ & $16 \%$ & $27 \%$ & $29 \%$ \\
\hline
\end{tabular}

Using Komeito's PR votes as estimates of the numbers of Komeito supporters in SMDs, ${ }^{17}$ we determine that each SMD has 25,945 Komeito supporters on average; or $12.8 \%$ of the total valid votes (minimum $=4.8 \%$; maximum $=25.3 \%$ ). Of course, we cannot assume that all Komeito supporters vote reliably for LDP candidates in SMDs simply because party leaders ask them to do so. The percentage of Komeito supporters who vote for the LDP in SMDs is almost certainly less than $100 \%$, and also fluctuates from election to election (Klein, 2013). Accordingly, we later offer a range of estimates based on different assumed support rates. First, however, we simulate counterfactual outcomes assuming an $80 \%$ support rate - a figure based on actual survey results from the 2012 general election. ${ }^{18}$ Table 1 shows what happens when $80 \%$ of Komeito's PR votes are subtracted from the LDP's SMD candidates' actual vote totals. These results provide a reasonable, if rough, estimate of how many LDP candidates would have lost without Komeito's cooperation.

The results are striking. In the 2017 Lower House election, for example, the number of LDP winners in SMDs plummets from 215 (78\% of LDP SMD candidates) to 153 (55\%). In other words, based on our simulation's assumptions, 62 LDP Dietmembers who won that year would not have been elected without Komeito's help.

In actuality, the LDP won 281 Diet seats (60\%) in 2017 - 215 SMD seats and 66 PR seats. This impressive performance gave the LDP what looks like a strong single-party majority. Yet the coalition persists and the LDP shows no signs of abandoning it. Why? Our analysis suggests the LDP's seemingly impressive Diet seat totals mask significant electoral weakness; in particular, the fact that cooperation with Komeito is a necessary condition for the single-party majority the LDP currently enjoys. Specifically, without Komeito supporters the LDP probably would have won 62 fewer seats, leaving it with merely $219(47.1 \%)$ - less than the majority needed to pass any legislation, and much further away from the $2 / 3$ majority required to pass the LDP's coveted constitutional amendment (see the next section). Such an inferior electoral outcome would also have made the formation of an anti-LDP coalition government - as happened in 1993 - far more likely, which would have left the LDP out of the government entirely.

But 2017 is only the most recent example. Across the seven elections from 2000 to 2017, using the survey justified $80 \%$ assumption we find that, of the 1,302 victorious LDP candidates in SMDs, roughly $30 \%$ were elected thanks to Komeito's support. Even if we change our assumptions for 2017 or assume variability in support rates across elections, the results are still practically significant.

we only focus on whether the candidates won in SMDs. The goal is to illustrate the vote loss LDP candidates would suffer if Komeito did not help them, and the substantive results will not change whether we define a 'win' as winning in an SMD or securing a seat. We also expect all SMD candidates prefer to win in their districts.

${ }^{17}$ One possible criticism of this approach is that Komeito's PR votes may include LDP supporters. Indeed, it is impossible to know with certainty how many LDP supporters actually heed the request and cast their PR ballots to Komeito. We thus candidly acknowledge that Komeito's PR votes may be slightly inflated. Yet, for reasons delineated in the Appendix, we believe this effect is probably small.

${ }^{18}$ The survey asked respondents' vote choice in PR and SMD. Excluding the respondents who voted for a Komeito candidate in SMD, 59 voted for Komeito in PR, out of which 47 voted for an LDP candidate in SMD (79.7\%). The survey dataset was gathered by the Association for Promoting Fair Elections and was provided by the Social Science Japan Data Archive, Center for Social Research and Data Archives, Institute of Social Science, University of Tokyo. 
For example, even if we change the assumed average Komeito voter support rate across the 2000-2017 elections to 60,70 , or $90 \%$, the consequences are still hugely significant for LDP strength in the Diet in all scenarios: 22, 25, and 33\% of all LDP SMD candidates, respectively, would probably not have won their seats across that time span.

These simulated results underscore our theoretical argument: Were it not for the post-1994 electoral system and the votes LDP candidates receive from Komeito supporters in SMDs since the 2000 election, after each election the composition of the Diet (and LDP influence) would probably have been dramatically different. To be sure, no other single party comes close to matching the LDP's performance in the past few elections, as measured in Diet seats - actual (with Komeito support) or simulated (without Komeito support). But the most theoretically and policy significant question is not whether the LDP is Japan's largest political party in the Diet. Rather, the question is how its electoral performance affects the LDP's ability to govern and push through its policies as it wishes them to be, or to deter the formation of a majority coalition of opposition parties. And in this regard, the extent to which LDP reliance on its much smaller junior coalition partner to win Diet seats shapes electoral outcomes is transformative. This inconspicuous political reality also comes with a practical cost: it allows Komeito to punch significantly above its weight in Diet seats when it comes to intra-coalition negotiations over policy issues about which its supporters care deeply. In key instances, this allows Komeito to force the LDP to make significant concessions, even on those issues the ostensibly dominant Abe and his party see as national security imperatives, foundational party objectives, and matters fundamental to his personal legacy.

\section{Punching above its weight: Komeito's policy leverage over the LDP}

The nature and extent of LDP electoral dependence on Komeito support is not merely theoretically interesting. In this section we extend the analysis of electoral effects to demonstrate the practically significant and independent effects of this mechanism for prime ministerial and cabinet policy decisionmaking. Specifically, we examine the concessions Komeito extracted from Abe and the LDP in the policy domain the latter have repeatedly identified as a top priority since their return to power in late 2012: national security affairs. Of greatest relevance are the Abe-era reform efforts concerning two major policy issues regarding which both parties' positions are transparent, longstanding, and differ significantly: 'collective self-defense' and revision of the constitution's Article 9 'peace clause.'

This case selection provides an analytically tractable and revealing metric for measuring Komeito influence over its much larger coalition partner. In methodological terms our case selection conforms to a 'least-likely' or 'hard' case analytical framework (Eckstein, 1975: 118). Both policy goals are - literally - foundational LDP objectives written into the 1955 charter that established the party. ${ }^{19}$ And since 2012, Abe has stated they are among his administration's top priorities; the public has returned the ruling coalition to power overwhelmingly in every national election under Abe's leadership; the LDP has occupied the overwhelming majority of coalition-held seats, and now enjoys single-party majorities in both houses; and Japan's strategic environment is objectively worsening, leading many to demand major reforms. For these reasons alone, we should not expect to find evidence of Abe and the LDP making major concessions to the much smaller and weaker Komeito. Note that, as shown in Figure 1, Komeito occupies an extreme minority - merely 9-11\% - of the seats held by the coalition since its return to power in 2012. If, however, such concessions do manifest - even in such 'hard' cases - then they would provide especially compelling support of our theoretical argument.

\subsection{Ideological incompatibility on high-salience policy issues}

Although partnership with Komeito brings major electoral advantages to the LDP, it is not without significant costs in terms of policy and image. This is especially true with Abe's deeply conservative

\footnotetext{
${ }^{19}$ The Party's founding platform called explicitly for a 'collective security system.' Liberal Democratic Party of Japan, To no Seiko, 15 November 1955.
} 
base, such as Nippon Kaigi, the largest right-wing organization in Japan which counts Abe as an advisor, as well as 16 of 20 members of Abe's third Cabinet and nearly $40 \%$ of all Dietmembers (mostly LDP) as members (Tawara, 2017). Though Komeito's ability to proactively set the Abe administration's agenda is admittedly limited, the evidence demonstrates that, contrary to recent claims in the literature, its influence over substantive policy outcomes - even on issues its much larger senior coalition partner considers urgent priorities - can be significant. ${ }^{20}$

The first case study revolves around an ambitious push by Abe's cabinet to transform the role of the JSDF within and beyond the U.S.-Japan alliance. Specifically, it sought to enable the JSDF to exercise collective self-defense - use force to defend an ally under attack - and to participate kinetically in collective security operations (e.g., the 1991 Persian Gulf War). Though it achieved partial success, a close reading makes clear the final July 2014 Cabinet Decision and subsequent (2015) Diet legislation fell far short of Abe and his allies' original objectives. Komeito played a central role in significantly watering both down during intra-coalition negotiations. The second case study involves Abe's years-long push to revise Article 9 of Japan's 1947 Constitution - an objective he has vowed repeatedly to achieve as prime minister. Again, however, and due in large part to Komeito resistance, what Abe actually proposed in May 2017 had become so weakened substantively as to - literally - be unrecognizable to leading politicians from Abe's own party. Anticipating significant Komeito resistance to his originally coveted path, Abe abandoned his party's longstanding position and instead adopted Komeito's.

What makes Komeito's ability to shape Abe's agenda in these 'hard cases' particularly striking is its limited representation within the Cabinet in foreign policy and national security posts, ${ }^{21}$ and the fact that both Article 9 revision and the related objective of achieving a more 'equal' alliance with the United States by allowing JSDF to participate in collective self-defense and collective security had been key priorities of the conservative LDP for decades. Furthermore, Abe himself had arguably been both objectives' most full-throated and consistent champion within the LDP over the past 15 years. Practically speaking, Abe and most LDP politicians see these measures as necessary steps to bolster deterrence in an increasingly unstable region shaped by a nuclear-armed North Korea, a rising China that is increasingly militarily powerful and coercively assertive over territory disputed with Japan, and deepening concerns about the credibility of U.S. security treaty commitments to Japan. For Abe and many other conservatives within the LDP, the persistence of restrictions on Japan's ability to use military force overseas have also been closely associated with lost prestige and national pride. From this perspective, eliminating these constraints and behaving internationally like a 'normal nation' ( futsu no kuni) is a national imperative fundamental to Abe's own legacy as a political leader (Abe and Okazaki, 2004; Abe, 2006). For these reasons, in April 2012 the LDP published a draft revision of the Constitution, numerous aspects of which - including a significantly revamped Article 9 - were deeply controversial, considered by some as right-wing and nationalistic. ${ }^{22}$ Since becoming prime minister again in 2012 Abe has declared constitutional revision to allow full exercise of collective self-defense 'necessary to safeguard the lives of the Japanese people' and 'the responsibility of our generation. ${ }^{23}$

The empirical analysis that follows demonstrates how despite - or, paradoxically, because of - the LDP's five consecutive national election victories since 2012 and its majority in the lower (since 2014) and upper (since 2016) houses, resistance from the pacifistic Komeito has been arguably the most salient and direct factor compelling Abe and his LDP allies to significantly dial back their ambitions. These case studies complement the findings of earlier policy papers noting Komeito's important

\footnotetext{
${ }^{20}$ See examples cited in (and counterargument provided by) Ehrhardt (2014b: 188).

${ }^{21}$ No Komeito politician has ever served in a Cabinet-level national security post - chief cabinet secretary, minister of foreign affairs, or minister of defense - or even as a vice minister of defense. The lone Komeito member of Abe's cabinets has served as Minister of Land, Infrastructure, Transportation, and Tourism.

${ }^{22}$ Nihon koku kenpo kaisei soan [Japan Constitution Revision Draft], Liberal Democratic Party, 27 April 2012. http:// constitution.jimin.jp/draft.

${ }^{23}$ Kyodo Tsushin, 1 March 2016; Japan Times, 9 May 2017.
} 
role moderating LDP national security ambitions during the 1990s and early 2000s, especially as Japan wrestled with how to respond to the 9/11 terrorist attacks (Boyd and Samuels, 2005: esp. 27-61).

The LDP's continued reliance on Komeito electoral cooperation thus comes with significant costs in terms of policy concessions on issues associated with core party beliefs, party brand, and the current prime minister's own ambitions and understanding of Japan's national security imperatives. Komeito's direct if inconspicuous role shaping these important policy outcomes through intra-coalition negotiations is generally overlooked. Komeito may not have been a sufficient factor in determining the result, but the available evidence suggests strongly that it was a necessary and direct one.

\subsection{Enabling 'Limited' collective self-defense in 2014}

On 1 July 2014, the Abe Cabinet pushed through a historic Cabinet Decision reinterpreting Japan's 1947 Constitution's Article 9 'peace clause' to allow the JSDF for the first time to exercise the UN Charter-sanctioned right to 'collective self-defense' (CSD); i.e., the use of force to aid an ally under attack. This controversial decision made global headlines and appeared to overturn 60 years of authoritative constitutional interpretations on the matter. Yet lost in the domestic and global hype surrounding the reinterpretation was a painful policy reality for Abe and his LDP allies: concessions made during multiple rounds of intra-coalition negotiations with Komeito imposed such strict, globally unique conditions on CSD that it is questionable whether Japan will ever exercise this right. Aware of this reality, even after the associated security legislation's passage in November 2015, Abe was again calling for formal constitutional revision to allow the 'full' exercise of CSD that the watereddown 2014 Cabinet decision had failed to achieve (see below).

Based on its longstanding view that full CSD exercise would be unconstitutional and to strike a balance between the LDP's ambition and concern about backlash from its pacifistic support base, Komeito extracted from the Abe Cabinet severely limiting conditions for use-of-force that were both unique to Japan and in core aspects basically consistent with government policy since 1954, which allowed individual self-defense.

Contemporaneous newspaper reports show clearly that Komeito negotiators were well aware that the party's base - the lay Buddhist organization Soka Gakkai - staunchly opposed both CSD and constitutional revision. ${ }^{24}$ Confronting intra-coalition resistance, Abe ultimately conceded on major points. Abe abandoned his call to make UN-sanctioned collective security operations requiring use-of-force (e.g., the 1991 Persian Gulf War) constitutional. For many advocates of a more active and 'normal' international role for the JSDF, Japan's inability to deploy or contribute it to exactly this kind of multinational operation has caused major damage to Japan's prestige. Yet Komeito opposition was fierce, and the issue was ultimately dropped. ${ }^{25}$ Komeito also resisted Abe's longstanding effort to enable the JSDF to exercise 'full' (unconditional) CSD as defined by international law, which would have enabled Japan to use force to defend other countries even when Japan's own security was not directly threatened. Ignoring his own hand-picked advisory panel's recommendation, Abe conceded that formal constitutional revision - not just reinterpretation - would be necessary to pass legislation enabling the JSDF to adopt these roles - a political bridge too far. ${ }^{26}$ Intra-coalition negotiations with Komeito - widely documented in Japanese press reports in spring/summer 2014 - shaped the language of the actual Cabinet Decision toward an LDP-Komeito agreement (goi) to impose various significant limitations on use-of-force, above all three conditions (san yoken) requiring an armed attack to have taken place which posed a 'clear danger' and threat to Japan's 'survival' (sonritsu); no alternative means of addressing the threat exist; and whatever force Japan uses must be limited to 'the minimum necessary' (Cabinet Secretariat, 2014). These self-imposed conditions thus narrowly

\footnotetext{
${ }^{24}$ Mainichi Shimbun, 24 September 2018.

${ }^{25}$ AJW, 28 June 2014.

${ }^{26}$ 'Press Conference by Prime Minister Abe' Prime Minister of Japan and His Cabinet, 15 May 2014. http://japan.kantei.go. jp/96_abe/statement/201405/0515kaiken.html.
} 
bounded the definition of self-defense to be unique to Japan, imposed a concrete link to previous governmental interpretations, and significantly limited the reinterpretation's effective significance for JSDF roles and missions (Liff, 2017). ${ }^{27}$

In sum, while the July 2014 shift in policy concerning CSD was indeed substantively unprecedented, the ultimate outcome was neutered significantly relative to what Abe and the LDP originally sought. The LDP's concessions are particularly notable given Abe and the LDP's apparently strong electoral mandate, consistently high Cabinet support ratings, and the enervated, fractious, and disorganized opposition parties at the time. Komeito's influence within the coalition appears to be the crucial and most direct factor that compelled the administration to moderate its ambitions. What began as Abe's initiative to formally revise the Constitution in line with an ambitious 2012 LDP draft revision of Article 9 ended with the Cabinet allowing only 'limited' CSD exercise under very strict conditions unique to Japan and roughly consistent with the basic logic of past government interpretations.

Komeito celebrated and promoted its victory to its base. Well aware of fervent opposition among Soka Gakkai members against Abe's push for 'full' CSD, following the July 2014 Cabinet Decision Komeito boasted about its role as an 'opposition party within the ruling coalition' and declared that its pushback had ensured 'the normative status' of Article 9. Komeito claimed that Japan would still not be able to defend another country in a manner written into the UN Charter; rather, self-defense would be strictly limited to 'cases virtually indistinguishable from cases of individual national self-defense' (essentially the government's decades-old interpretation). ${ }^{28}$ The chairman of Soka Gakkai later staked out a virtually identical position and lauded the party's crucial role preventing Abe and his party from enabling their long-cherished dream of full CSD exercise. ${ }^{29}$ Even so, the 2017 election - which saw Komeito drop from 35 to 29 Lower House seats and garner its lowest vote total in the PR tier since the coalition was formed - may indicate the party is facing a backlash from Soka Gakkai members for not resisting the LDP even more severely (Klein and McLaughlin, 2018).

\subsection{Constitutional revision: Komeito wins without fighting}

The July 2016 Upper House election provided what the global media and many analysts widely asserted was a game-changer when so-called 'pro-constitutional revision forces' attained two-thirds majorities in both Diet chambers - thus seemingly providing one of two preconditions for formal constitutional revision. ${ }^{30}$ To many observers, the stars appeared to be aligned for the LDP - and Abe - to achieve its long-desired goal of constitutional revision. Any modification would be significant; Article 9 is a defining feature of Japan's foreign policy posture and its role within the U.S.-Japan alliance. On 3 May 2017, Abe formally announced a concrete plan to revise Japan's 1947 constitution.

Lost in the excited noise surrounding the possibility of any constitutional revision was the surprising fact that the actual amendment Abe called for that day bore no resemblance to six decades of past LDP positions, and departed fundamentally from both Abe's own past stated preferences and his party's most recent draft constitution revision proposals (published in 2005 and 2012). On the contrary, his May 2017 proposal had a remarkable genesis: a 2004 proposal from Komeito (see Table 2). Thus, on closer inspection, the actual substance of Abe's proposal made clear that, before the press conference even began, he had already made a significant concession to the LDP's junior coalition partner.

Specifically, in a major departure from past LDP positions, Abe's 2017 revision proposal called for the two existing clauses of Article 9 to remain untouched. Instead, he advocated merely adding a new clause to explicitly stipulate the constitutionality of the JSDF's existence - by 2017 already a popular

\footnotetext{
${ }^{27}$ Asahi Shimbun, 25 June 2014; 'Komeito's efforts to ensure maintenance of defense-only policy', Komeito, 17 July 2015. https://www.komei.or.jp/en/news/detail/20150717_18019.

${ }^{28}$ 'Heiwashugi no hashira wo kenji', Komeito, 2 July 2014. https://www.komei.or.jp/news/detail/20140702_14363. Also see McLaughlin et al. (2014).

${ }^{29}$ Asahi Shimbun, 22 September 2016.

${ }^{30}$ The other condition is a public referendum requiring simple majority support.
} 
Table 2. Comparative analytics on LDP and Komeito constitutional revision proposals ${ }^{a}$

\begin{tabular}{|c|c|c|c|}
\hline & LDP proposal (2012) & Komeito proposal (2004) & $\begin{array}{l}\text { Proposal pushed by (LDP) } \\
\text { PM Abe (2017) }\end{array}$ \\
\hline Basic approach & $\begin{array}{l}\text { Wholesale revision of the entire text } \\
\quad \text { (kaiken) }\end{array}$ & $\begin{array}{l}\text { Do not revise existing text } \\
\text { Instead, add amendments } \\
\text { as needed (kaken) }\end{array}$ & $\begin{array}{l}\text { Do not revise existing text } \\
\text { Instead, add amendments } \\
\text { as needed (kaken) }\end{array}$ \\
\hline Article 9, Clause 1 & $\begin{array}{l}\text { Revise, including: } \\
\text { - to explicitly stipulate } \\
\text { constitutionality of } \\
\text { 'self-defense' (presumably, } \\
\text { both individual and collective) }\end{array}$ & Do not revise & Do not revise \\
\hline Article 9, Clause 2 & $\begin{array}{l}\text { Fundamentally rewrite; including: } \\
\text { - to delete line stating that 'land, } \\
\text { sea, and air forces will never be } \\
\text { maintained' and that 'the right } \\
\text { of belligerence of the state will } \\
\text { not be recognized' } \\
\text { - renaming JSDF as 'National } \\
\text { Defense Force' } \\
\text { - stipulating constitutionality of } \\
\text { use of force in collective } \\
\text { security operations }\end{array}$ & Do not revise & Do not revise \\
\hline $\begin{array}{l}\text { Article 9, New } \\
\text { Clause(s) or New } \\
\text { Separate Article }\end{array}$ & $\begin{array}{l}\text { New clause stipulating the state and } \\
\text { people's responsibility to } \\
\text { safeguard Japan's territorial } \\
\text { sovereignty and resources }\end{array}$ & $\begin{array}{l}\text { Add clause or separate article } \\
\text { to separately stipulate the } \\
\text { constitutionality of JSDF } \\
\text { (jieitai no sonzai no meiki) }\end{array}$ & $\begin{array}{l}\text { Add clause or separate article } \\
\text { to separately stipulate the } \\
\text { constitutionality of JSDF } \\
\text { (jieitai no sonzai no meiki) }\end{array}$ \\
\hline
\end{tabular}

a'Nihon koku kenpo kaisei soan,' 4-5. Komeito view dates back to the party's October 2004 convention. See Asahi Shimbun, November 1 , 2004.

status quo supported by overwhelming majorities of the public and one which, although inconsistent with a literal reading of Article 9's actual text, had been basically reflected in the official governmental interpretation and policy since 1954. Abe's 2017 proposal thus might as well have been announced by Komeito itself. No wonder it was unrecognizable to major figures in the LDP, ${ }^{31}$ whereas Komeito leaders welcomed Abe's proposal as 'in line with Komeito's stance,' even highlighting for its base that the proposal bore no resemblance to past LDP proposals. ${ }^{32}$

As with the 2014 Cabinet decision on CSD, here, too, Komeito's influence was inconspicuous. Yet it was immensely consequential in any practical sense. Specific to Article 9, the ex-ante respective desired approaches and end states of the ruling coalition partners were on record and differed fundamentally. In its two major previous proposals for Article 9 revision - in 2005 and 2012 - the LDP had unabashedly called for either significantly revising or deleting entirely the article's second clause (which denies the maintenance of 'war potential' and 'the right of belligerency of the state') to enable ambitious changes to the form and function of Japan's de facto military - including enabling those missions that had ultimately been denied as part of the 2014 reinterpretation. In contrast, since 2004 Komeito had called for an approach merely making explicit in the constitution a policy reality since 1954: the constitutionality of JSDF. Leaving the second clause untouched therefore constituted a

\footnotetext{
${ }^{31}$ The spring 2012 LDP draft provides the most useful metric for baselining the LDP's official, unalloyed consensus view because it was compiled while the party was in opposition and out of coalition with Komeito.

${ }^{32}$ Yomiuri Shimbun, 4 May 2017; Yomiuri Shimbun, 9 May 2017.
} 
major LDP concession, especially since Abe himself had earlier stated that its revision or elimination would be a precondition for Japan to be able to fully exercise CSD. ${ }^{33}$ In short, prime minister Abe effectively abandoned the LDP's longstanding position in favor of a significantly watered-down revision proposal that Komeito would accept.

The extent and practical significance of Abe's concession was reflected in the bewildered responses of major players within the LDP. Shigeru Ishiba - a veteran LDP politician, former defense minister, and a leading candidate to succeed Abe as party president (and thus prime minister) - criticized Abe for his May 2017 proposal. Significantly, Ishiba revealed that the proposal had never even been discussed within the LDP itself, and criticized it as ignoring years of accumulated debate within the party. ${ }^{34}$ Ishiba argued further that there was even an intra-LDP consensus that the approach Abe proposed was unacceptable. ${ }^{35}$

Later that month, various top LDP leaders - including Abe himself - basically acknowledged the concession and the coalition logic which informed it. For his part, Abe recognized the chosen additive (kaken) approach as Komeito's 'long-held position' and emphasized that his embrace of it was a pragmatic move driven by political necessity. LDP Vice-president Masahiko Komura went so far as to explicitly acknowledge the prime minister's personal preference for deleting the second clause entirely, but again referenced the practical necessity of compromising with the LDP's junior coalition partner. ${ }^{36}$ When at an intimate dinner a well-known international security scholar beseeched Abe to eliminate the second clause of Article 9 'to fulfill a responsibility of our generation,' the prime minister responded straightforwardly, saying: 'It would never get through Komeito. It's impossible.,37

In the final analysis, Abe's May 2017 Article 9 revision proposal was based on a Komeito framework. It categorically ignored and was inconsistent with both the LDP's previous (2005 and 2012) proposals, not to mention the party's 1955 founding charter, as well as the prime minister's own long-held personal position on the issue. Likely anticipating major intra-LDP pushback, as head of the coalition and government Abe bypassed debate within his own party and put forward the Komeito-supported approach in a 'top-down' manner. ${ }^{38}$

In both cases detailed in this section the LDP's significant concessions make clear why many of Abe's supporters on the right would like to see him abandon Komeito; so that he has more policymaking freedom. Indeed, the Party of Future Generations argued this very point (Pekkanen and Reed, 2016). Yet, this study's earlier argument makes clear why this would be far easier said than done, if not ultimately self-defeating. These strange bedfellows will be difficult to separate - unless, of course, the electoral system is changed.

\section{Conclusion}

What explains a stable, 20-year partnership in and out of government between political parties with vastly different ideologies and support bases? The longevity, closeness, and nature of the LDPKomeito partnership present a challenge for conventional theories of coalition politics. For example, it does not have characteristics typically associated with pre-electoral coalitions (Golder, 2006). Furthermore, the partnership is costly to both parties in branding and policy terms, even forcing each party to make major concessions on core issues closely associated with foundational party identities and national security. Still more puzzling, despite enjoying single-party majorities in both Diet houses today the (much-larger) LDP still shows no signs of even considering abandoning Komeito.

We attribute the puzzling longevity of the LDP-Komeito partnership primarily to incentives induced by Japan's mixed electoral system. Electoral cooperation between the LDP and Komeito

\footnotetext{
${ }^{33}$ Kyodo News, 30 January 2018.

${ }^{34}$ Mainichi Shimbun, 4 May 2017.

${ }^{35}$ Japan Times, 24 May 2017; Sankei Shimbun, 2 July 2017.

${ }^{36}$ Asahi Shimbun, 25 May 2017.

${ }^{37}$ Mainichi Shimbun, 12 October 2017.

${ }^{38}$ Asahi Shimbun, 25 May 2017.
} 
takes the form of mutual stand-down agreements, which render many LDP candidates dependent on Komeito supporters to get elected in SMDs. Meanwhile, many Komeito Dietmembers would not be elected if the LDP were to nominate competing candidates. Japan's electoral system has thus enabled a remarkably durable, codependent relationship of strange bedfellows difficult for either party to forsake. It has created an incentive structure conducive to the formation and maintenance of this type of coalition - one unlikely to be found in countries with pure PR systems. Nevertheless, the electoral system does not appear to be a sufficient condition for such a coalition to form. The analysis herein suggests additional, more idiosyncratic factors - such as party organization and support base characteristics - also play a central role in the LDP-Komeito coalition's genesis and durability. As such, we should not necessarily expect to see a similar coalition in similar electoral systems, e.g., South Korea and Taiwan. In any event, analysis of this understudied but important case sheds light on a mechanism generally overlooked by students of coalition politics - one whose practical political and policy consequences can be significant. Komeito's ability to flex its muscles, punching significantly above its weight in Diet seats, manifests even on issues the powerful, long-serving current LDP prime minister identifies as his top policy priorities. It also is yet another example of the major but often inconspicuous domestic constraints Abe and his allies continue to confront in the national security domain (Liff, 2018).

In 2019, the LDP-Komeito partnership marks its 20th anniversary. Like some marriages, it has become an equilibrium characterized by significant disputes and tension between two very different partners yet also deep mutual dependence from which it would be difficult, and very costly, for either party to depart.

The result of the July 2017 Tokyo metropolitan assembly election, a rare case of Komeito not cooperating with the LDP in a major election, threw the political reality of LDP dependence on Komeito into sharp relief. The LDP suffered the worst defeat in its history, losing 34 of its 57 seats. In contrast, Komeito increased its seat total. When the dust had settled, the LDP managed to elect only as many assembly members - 23 - as the much smaller Komeito. Even more revealing of the strength and reliability of Komeito voters was the fact that although only $38 \%$ (23 of 60 ) of LDP candidates won a seat, all 23 Komeito candidates were victorious. That evening, various experts wondered aloud whether intense friction between the parties in a major local election in the nation's capital heralded the end of LDP-Komeito cooperation in national coalitions. Within hours, however, representatives from both parties reaffirmed their commitment to ruling in coalition and to continuing their close coordination in national elections. Yet the cat was out of the bag. As one mid-ranking LDP member candidly admitted, 'The assembly election results revealed that we cannot win an election without the support of Komeito. It's inevitable that Komeito's influence will increase. ${ }^{39}$

The initial formation of the LDP-Komeito coalition of strange bedfellows in 1999 was principally motivated by the LDP's lack of an upper house majority and desire to combine the two parties' seats together in pursuit of a controlling majority. Yet what began 20 years ago as an opportunistic shortterm calculation best explained by basic Diet seat arithmetic - an origin story familiar to any student of coalition politics - is no longer thus. The nature and depth of the LDP-Komeito partnership has undergone a qualitative and quantitative transformation that has made it fundamental to explaining national election results and major policy outcomes in Japan over the past 20 years. Because of its theoretical (and real-world) significance, its causes deserve far greater attention from coalition politics scholars than it has received.

There are numerous examples across the world's democracies in which policy disputes on core issues sound the death knell for a coalition. In contrast, in Japan, the parties in coalition compromise policies greatly in order to avoid a divorce that would be devastating to both parties' electoral prospects. Beyond its implications for theories of coalition durability, the LDP-Komeito case thus also demonstrates that being in a coalition can induce greater and more sustainable policy compromises than the existing literature suggests - even in a case where the senior partner appears dominant,

\footnotetext{
${ }^{39}$ The Japan News, 4 July 2017.
} 
holding roughly $90 \%$ of the coalition's Diet seats in the Lower House. Parties with vastly different support bases, brands, and policy preferences can develop a codependent and durable partnership, and their efforts to avoid a costly breakup through policy compromises helps maintain it. The associated findings in this study provide new insights for students of coalition politics.

The drivers and nature of the LDP-Komeito coalition also have major ramifications for executive and parliamentary decision-making in key policy areas, which in turn powerfully shape not only Japan's domestic politics, but also its foreign policy trajectory and alliance with the United States. Without appreciating the influence of this inconspicuous dynamic, it is difficult to understand the significant, albeit typically underappreciated influence Komeito has over its (vastly) larger coalition partner in intra-coalition policy negotiations on issues of fundamental importance to the prime minister and his LDP allies. This dynamic also explains why Japan's dominant post-war party opts to continue the costly partnership despite enjoying single-party majorities in both Diet houses. It is in significant part because of, rather than despite, Komeito that the LDP maintains the Diet strength and policy influence it has today.

Acknowledgments. An earlier version of this paper was presented at the April 2017 annual meeting of the Midwest Political Science Association in Chicago. The authors would like to thank Dominik Duell and Steven Reed, as well as the journal's Editors and several anonymous reviewers, for helpful comments on earlier versions of this paper.

\section{References}

Abe Shinzo (2006) Utsukushii Kuni E [Toward A Beautiful Country]. Tokyo: Bungei Shunju.

Abe Shinzo and Hisahiko Okazaki (2004) Kono Kuni wo Mamoru Ketsui [Determination to Protect This Nation]. Tokyo: Fusosha.

Axelrod R (1970) Conflict of Interest, Chicago: Marham.

Boyd JP and Samuels RJ (2005) Nine Lives? The Politics of Constitutional Reform in Japan. Washington, DC: East-West Center.

Butler DM and Neff Powell E (2014) Understanding the party brand: experimental evidence on the role of valence. Journal of Politics 76, 492-505.

Cabinet Secretariat (Japan) (2014) Kuni no sonritsu wo mattoshi, kokumin wo mamoru tame no kireme no nai anzen hosho hosei no seibi ni tsuite [Cabinet Decision on the Development of Seamless Security Legislation to Ensure Japan's Survival and Protect Its People], 1 July 2014. Available at http://www.cas.go.jp/jp/gaiyou/jimu/pdf/anpohosei.pdf.

Castles FG and Mair P (1984) Left-right political scales: some 'expert' judgements. European Journal of Political Research 12, 73-88.

Charnock D and Ellis P (2003) The structure of the Australian party system and its strategic consequences. Australian Journal of Political Science 38, 423-443.

Cox GW and McCubbins MD (1993) Legislative Leviathan. Berkeley: University of California Press.

Curtis GL (1999) The Logic of Japanese Politics. New York: Columbia University Press (in paperback edition).

de Swaan A (1973) Coalition Theories and Government Formation. Amsterdam: Elsevier.

Diermeier D and Stevenson RT (1999) Cabinet survival and competing risks. American Journal of Political Science 43, 1051-1068.

Duverger M (1954) Political Parties: Their Organisation and Activity in the Modern State. New York: Wiley.

Eckstein H (1975) Case studies and theory in political science. In Greenstein F and Polsby N (eds), Handbook of Political Science, vol. 7. Reading, MA: Addison-Wesley, pp. 79-138.

Ehrhardt G (2014a) How Komeito politicians get elected. In Ehrhardt G, Klein A, McClaughlin L and Reed SR (eds), Kōmeitō: Politics and Religion in Japan. Berkeley: Institute of East Asian Studies, pp. 113-138.

Ehrhardt G (2014b) Housewife voters and Komeito policies. In Ehrhardt G, Klein A, McClaughlin L and Reed SR (eds), Kōmeitō: Politics and Religion in Japan. Berkeley: Institute of East Asian Studies, pp. 187-211.

Ehrhardt G, Klein A, McClaughlin L and Reed SR (eds) (2014a) Kōmeitō: Politics and Religion in Japan. Berkeley: Institute of East Asian Studies.

Ehrhardt G, Klein A, McClaughlin L and Reed SR (2014b) Kōmeitō: the most understudied party of Japanese politics. In Ehrhardt G, Klein A, McClaughlin L and Reed SR (eds), Kōmeitō: Politics and Religion in Japan. Berkeley: Institute of East Asian Studies, pp. 3-22.

Golder SN (2006) The Logic of Pre-Electoral Coalition Formation. Columbus: Ohio State University Press.

Hasunuma L and Klein A (2014) Komeito in coalition. In Ehrhardt G, Klein A, McClaughlin L and Reed SR (eds), Kōmeitō: Politics and Religion in Japan. Berkeley: Institute of East Asian Studies, pp. 240-265.

Kawato S (2002) Senkyo kyoryoku, senryaku tohyou, seiji shikin: 2000 nen sousenkyo no bunseki. Senkyo Kenkyu 17. 
Klein A (2013) Komeito - The first third wave. In Pekkanen R, Reed SR and Scheiner E (eds), Japan Decides 2012: The Japanese General Election. New York, NY: Palgrave, pp. 84-98.

Klein A and McClaughlin L (2018) Kōmeitō 2017: new complications. In Pekkanen RJ, Reed SR, Scheiner E and Smith DM (eds), Japan Decides 2017: The Japanese General Election. New York, NY: Palgrave, pp. 53-76.

Klein A and Reed SR (2014a) Religious groups in Japanese electoral politics. In Ehrhardt G, Klein A, McClaughlin L and Reed SR (eds), Kōmeitō: Politics and Religion in Japan. Berkeley: Institute of East Asian Studies, pp. 25-48.

Klein A and Reed SR (2014b) Anti-Kōmeitō counter-mobilizations. In Ehrhardt G, Klein A, McClaughlin L and Reed SR (eds), Kōmeitō: Politics and Religion in Japan. Berkeley: Institute of East Asian Studies, pp. 215-239.

Krauss ES and Pekkanen RJ (2010) The Rise and Fall of Japan's LDP: Political Party Organizations as Historical Institutions. Ithaca: Cornell University Press.

Laver M (2003) Government termination. Annual Review of Political Science 6.

Laver M and Schofield N (1990) Multiparty Government: The Politics of Coalition in Europe. Oxford: Oxford University Press.

Leiserson M (1968) Factions and coalitions in One-party Japan: an interpretation based on the theory of games. American Political Science Review 62, 770-787.

Liff AP (2017) Policy by other means: collective self-defense and the politics of Japan's postwar constitutional interpretations. Asia Policy 24, 139-172.

Liff AP (2018) Japan's security policy in the 'Abe era': radical transformation or evolutionary shift? Texas National Security Review 1, 8-34.

Lijphart A (1994) Electoral Systems and Party Systems: A Study of Twenty-Seven Democracies, 1945-1990. New York: Oxford University Press.

Lijphart A (2012) Patterns of Democracy: Government Forms and Performance in Thirty-Six Countries, 2nd Edn. New Haven: Yale University Press.

Lupia A and Strøm K (1995) Coalition termination and the strategic timing of parliamentary elections. American Political Science Review 89, 648-665.

Maeda Ko (2009) Has the electoral system reform made Japanese elections party-centered? In Reed SR, Shimizu K and Mori McElwain K (eds), Political Change in Japan: Electoral Behavior, Party Realignment, and the Koizumi Reforms. Stanford: Shorenstein APARC, pp. 47-66.

Martin LW and Stevenson RT (2001) Government formation in parliamentary Democracies'. American Journal of Political Science 45, 33-50.

McLaughlin L (2014) Electioneering as religious practice. In Ehrhardt G, Klein A, McClaughlin L and Reed SR (eds), Kōmeitō: Politics and Religion in Japan. Berkeley: Institute of East Asian Studies, pp. 51-82.

McLaughlin L, Klein A and Reed SR (2014) The Power of Japan's Religious Party, Wilson Center, 4 December 2014. Available at https://www.wilsoncenter.org/article/the-power-japans-religious-party

Müller WC and Strom K (eds) (1999) Policy, Office, or Votes?: How Political Parties in Western Europe Make Hard Decisions. Cambridge: Cambridge University Press.

Müller WC and Strom K (eds) (2000) Coalition Governments in Western Europe. Oxford: Oxford University Press.

Onizuka Naoko (2002) Chusho seito no renritsu seiken sanka to yukensha no tohyo kodo. Senkyo Kenkyu 17.

Pekkanen RJ and Reed SR (2016) From third force to third party: duverger's revenge? In Pekkanen R, Reed SR and Scheiner E (eds), Japan Decides 2014: The Japanese General Election. New York, NY: Palgrave, pp. 62-71.

Riker WH (1962) The Theory of Political Coalitions. New Haven: Yale University Press.

Smith DM (2014) Party ideals and practical constraints in Komeito candidate nominations. In Ehrhardt G, Klein A, McClaughlin L and Reed SR (eds), Kōmeitō: Politics and Religion in Japan. Berkeley: Institute of East Asian Studies, pp. 139-162.

Strom K, Budge I and Laver MJ (1994) Constraints on cabinet formation in parliamentary democracies. American Journal of Political Science 38, 303-335.

Tanaka Aiji (2012) Mutohaso no kore made to genzai [Unaffiliated Voters: Then and Now] Nippon.com, July 18, 2012. Available at http://www.nippon.com/ja/in-depth/a01104/

Tawara Yoshifumi (2017) What is the aim of Nippon Kaigi, the ultra-right organization that supports Japan's Abe administration? Asia-Pacific Journal Japan Focus 15. Available at http://apjjf.org/2017/21/Tawara.html

\section{Appendix: Are Komeito's PR votes good estimates for the size of Komeito supporters?}

In an earlier section, we used Komeito's PR votes as estimates of the number of votes Komeito supporters cast for LDP candidates in SMDs. If LDP supporters voted for Komeito in the PR tier to return the favor, we would be overestimating the size of Komeito votes added to LDP candidates' SMD votes. However, our claim that that number of LDP supporters who voted for Komeito in PR is not large enough to contaminate our analysis is based on the following evidence: 
(1) In the 1998 upper house election, which was the last national-level election held before the LDP-Komeito partnership began, Komeito's PR vote share was $13.8 \%$. We can treat this percentage as a baseline measure of Komeito support. Since electoral cooperation began, Komeito's PR vote share has not changed significantly. The average Komeito PR vote share in the past 12 elections (six lower house and six upper house) is $13.6 \%$ (13.1\% for the lower house and 14.1 for the upper house). The lowest is $11.5 \%$ (2009 lower house), and the highest is $15.4 \%$ (2004 upper house). ${ }^{40}$

(2) Komeito nominates candidates in some large districts in upper house elections. Those districts also have LDP candidates. In such districts, LDP and Komeito supporters must vote independently (without coordination), and we can use the electoral results from those districts as good estimates of the size of Komeito support. In the 2013 upper house election, Komeito's candidate in Tokyo, Toshiko Takeya, obtained 770,535 votes. In the 2016 upper house election, Komeito's Natsuo Yamaguchi in the Tokyo district won 797,811 votes. In the PR tier of those upper house elections, Komeito obtained 688,535 and 710,528 votes, respectively, in Tokyo. Those numbers roughly show the size of Komeito support in Tokyo. If Komeito's PR votes in lower house elections include a sizable number of votes from LDP supporters due to their cooperation, we should see Komeito winning more PR votes in lower house elections than the numbers shown above. However, it won 700,127 votes in Tokyo in the 2014 lower house election. ${ }^{41}$

The evidence above thus suggests strongly that the number of LDP supporters who vote for Komeito in the PR tier of lower house elections is not large. We are therefore confident that Komeito's PR vote totals in lower house elections are reasonably good estimates of the amount of votes LDP SMD candidates obtain from Komeito supporters.

Adam P. Liff is an assistant professor of East Asian international relations at Indiana University's Hamilton Lugar School of Global and International Studies, where he directs the 21st Century Japan Politics and Society Initiative. He is also associate-in-research at Harvard University's Reischauer Institute of Japanese Studies and Fairbank Center for Chinese Studies. Liff holds a Ph.D. and M.A. in politics from Princeton University, and a B.A. from Stanford University.

Ko Maeda is an associate professor in the Department of Political Science at the University of North Texas. He received his Ph.D. in political science from Michigan State University and his B.A. from the University of Tsukuba (Japan).

\footnotetext{
${ }^{40}$ Aggregate electoral results of national elections were obtained from http://www.soumu.go.jp/senkyo/senkyo_s/data/ index.html, accessed on 9 February 2017.

${ }^{41}$ Electoral results in Tokyo were obtained from http://www.senkyo.metro.tokyo.jp/election/, accessed on 9 February 2017
}

Cite this article: Liff AP, Maeda K (2019). Electoral incentives, policy compromise, and coalition durability: Japan's LDPKomeito Government in a mixed electoral system. Japanese Journal of Political Science 20, 53-73. https://doi.org/10.1017/ S1468109918000415 